\title{
Evaluation of recombinant Cryptosporidium hominis GP60 protein and anti-GP60 chicken polyclonal IgY for research and diagnostic purposes
}

Avaliação da proteína recombinante GP60 de Cryptosporidium hominis e da IgY policlonal anti-GP60 recombinante para uso em pesquisa e diagnóstico

Valéria Chamas Miura ${ }^{1,2}$; Sérgio Moraes Aoki²; Paulo Peitl Junior²; Lilian Campos Pires²; Priscila Dalmagro²; Alex Akira Nakamura'; Marcelo Vasconcelos Meireles ${ }^{1 *}$

\author{
${ }^{1}$ Faculdade de Medicina Veterinária, Universidade Estadual Paulista - UNESP, Araçatuba, SP, Brasil \\ ${ }^{2}$ DNApta Biotechnology Ltda., Sáo José do Rio Preto, SP, Brasil
}

Received March 9, 2017

Accepted May 19, 2017

\begin{abstract}
In this study, a method for expressing Cryptosporidium hominis GP60 glycoprotein in Escherichia coli for production of polyclonal anti-GP60 IgY in chickens was developed aiming future studies concerning the diagnosis, prevention and treatment of cryptosporidiosis. The full-length nucleotide sequence of the $C$. hominis gp 60 gene was codon-optimized for expression in E. coli and was synthesized in pET28-a vector. Subcloning was performed on several different strains of BL21 E. coli. Temperature, time and inducer IPTG concentration assays were also performed and analyzed using SDS-PAGE. The optimal conditions were observed at a temperature of $37^{\circ} \mathrm{C}$, with overnight incubation and $1 \mathrm{mM}$ of IPTG. Purification was performed by means of affinity chromatography using the AKTA Pure chromatography system and the Hi-Trap ${ }^{\mathrm{TM}} \mathrm{HP}$ column (GE Healthcare). The recombinant protein GP60 (rGP60) thus generated was used to immunize laying hens owing the production of polyclonal IgY. Western blot and indirect immunofluorescence showed that the polyclonal antibody was capable of binding to rGP60 and to Cryptosporidium parvum sporozoites, respectively. The rGP60 and the IgY anti-rGP60 generated in this study may be used as templates for research and for the development of diagnostic methods for cryptosporidiosis.
\end{abstract}

Keywords: Cryptosporidium, glycoprotein GP60, polyclonal antibody, diagnosis.

\section{Resumo}

Neste trabalho, foi desenvolvido um método de expressão da glicoproteína GP60 de Cryptosporidium hominis em Escherichia coli visando produzir anticorpos IgY anti-GP60 em galinhas para utilizaçáo em estudos futuros com os objetivos de diagnóstico, prevençáo e tratamento da criptosporidiose. A sequência completa de nucleotídeos do gene gp60 de C. hominis foi códon-otimizada para expressão em $E$. coli e sintetizada no vetor pET28-a. A subclonagem foi realizada em várias estirpes diferentes de E. coli BL21. Os ensaios de concentraçáo do indutor IPTG, temperatura e tempo foram realizados e analisados por SDS-PAGE. As condiçōes ótimas de expressão foram observadas em temperatura de $37^{\circ} \mathrm{C}$, incubação durante a noite e $1 \mathrm{mM}$ de IPTG. A purificação da proteína foi realizada por cromatografia de afinidade utilizando o sistema de cromatografia AKTA Pure e a coluna Hi-Trap ${ }^{\text {TM }}$ HP (GE Healthcare). A proteína recombinante GP60 (rGP60) foi utilizada para imunizar galinhas poedeiras para produzir IgY policlonal anti-rGP60. Verificou-se por Western blot e por imunofluorescência indireta que o anticorpo policlonal apresentou reatividade com a rGP60 e com esporozoítos de Cryptosporidium parvum, respectivamente. A rGP60 e a IgY anti-rGP60 geradas neste estudo podem ser utilizadas como modelos para o desenvolvimento de ensaios para pesquisa e diagnóstico da criptosporidiose.

Palavras-chave: Cryptosporidium, glicoproteína GP60, anticorpo policlonal, diagnóstico.

${ }^{*}$ Corresponding author: Marcelo Vasconcelos Meireles. Faculdade de Medicina Veterinária, Universidade Estadual Paulista - UNESP, Rua Clóvis Pestana, 793, Bairro Dona Amélia, CEP 16050-680, Araçatuba, SP, Brasil. e-mail: marcelo@fmva.unesp.br 


\section{Introduction}

Human cryptosporidiosis is caused predominantly by Cryptosporidium hominis and Cryptosporidium parvum (CACCIÒ \& POZIO, 2006; XIAO \& RYAN, 2004). Outbreaks of human cryptosporidiosis are associated with ingestion of oocysts that are present in food sources or in recreational or drinking water, and with direct or indirect contact with human or animal feces (FAYER et al., 2000; KARANIS et al., 2007; LEITCH \& HE, 2012).

Cryptosporidiosis is usually diagnosed through staining techniques on fecal smears, aimed towards detecting oocysts. Besides being laborious and time-consuming, these techniques require high levels of experience for interpreting the results and have low sensitivity. Commercial immunological assays (direct fluorescent antibody assay and antigen capture enzyme-linked immunoassays) and molecular methods are also used and generally exhibit higher sensitivity and specificity than staining techniques (JEX et al., 2008).

Although several genetic markers are used for specific identification of Cryptosporidium, the most commonly used locus for subtyping in molecular epidemiology studies is the gp 60 gene, which encodes the glycoprotein GP60. This gene is of great importance in molecular epidemiology due to its several regions of high polymorphic rates (STRONG et al., 2000). C. hominis has six subtypes of the gp60 gene, and subtype Ib is the dominant and most widely distributed form (JEX \& GASSER, 2010; FOURNET et al., 2013).

Besides being a prominent molecular marker, the gp 60 gene has functional significance because the GP60 glycoprotein is associated with adhesion of the parasite to the host cell (CEVALLOS et al., 2000; O'CONNOR et al., 2007). Therefore, it is a potential candidate for developing new drugs, vaccines, diagnostic methods and treatment options for cryptosporidiosis (PREIDIS et al., 2007).

Production of polyclonal antibodies (IgY class) in laying hens, through extraction of immunoglobulin from egg yolk, is an innovative and expanding branch of biotechnology (PAULY et al., 2009). Replacement of mammalian immunoglobulins by chicken $\mathrm{IgY}$ for developing immunological diagnostic tests has several advantages like lower cost, ease of sampling, large quantities of antibodies recovered from egg yolks, high affinity and specificity of antibodies, ease of purification and no need to bleed or sacrifice animals (SCHADE et al., 2005; PAULY et al., 2009).

Thus, development of diagnostic methods using the recombinant protein GP60 (rGP60) and anti-rGP60 IgY provides promising diagnostic tools, as well as further knowledge for future studies with the objectives of detection, prevention and treatment of cryptosporidiosis. The present study aimed to clone, express and purify the rGP60 glycoprotein of $C$. hominis and immunize laying hens in order to obtain polyclonal anti-rGP60 IgY.

\section{Material and Methods}

Animal Research Ethics approval has been obtained from School of Veterinary Medicine of Araçatuba Committee for Ethical Use of Animals (FOA-00554-2013).

\section{Codon optimization and gp60 gene synthesis}

The full-length sequence of the $C$. hominis gp 60 gene, subtype Ib (GenBank FJ839882), consisting of 1008 base pairs and 335 amino acids, was used as a reference gene. A polyhistidine tail, start and stop codons and restriction sites (XbaI and XhoI) were added to the gp60 gene sequence. The full insert sequence was synthesized after being modified to optimize codon use for E. coli (PUIGBO et al., 2007), for cloning into the pET28-a vector.

\section{Transformation}

The TransformAid bacterial transformation kit (Thermo Fisher Scientific) was used to transform the vector pET28-a-gp60 in E. coli JM107 cells. The successful clones were purified using the five-minute GenElute ${ }^{\mathrm{TM}}$ plasmid miniprep kit (Sigma-Aldrich). This step was included only for expansion and storage of the resulting plasmids.

\section{Expression of GP60 protein}

\section{Selection of E. coli strains}

The plasmid thus generated (pET28a-gp60) was transformed into competent cells of different strains of E. coli BL21: $\mathrm{Xjb}$ Autolysis (Zymo Research), Rosetta (DE3), pLysS, CodonPlus, pRARE, C41 (DE3) and C43 (DE3). These last five strains were provided by the Virology Laboratory, School of Medicine of São José do Rio Preto (FAMERP).

\section{Transformation in competent E. coli cells}

The Z-Competent Cell ${ }^{\text {TM }}$ transformation kit (Zymo Research) was used to make competent $E$. coli strains, in accordance with the manufacturer's instructions.

A mix of $100 \mathrm{~mL}$ of each competent bacterium and $5 \mu \mathrm{L}$ of the purified plasmid construction pET28a-gp60 was used for each transformation. Aliquots of transformed bacteria were grown on culture plates with LB solid medium containing kanamycin, at a final concentration of $20 \mathrm{mg} / \mathrm{mL}$, for approximately 16 hours at $37^{\circ} \mathrm{C}$. A culture of each colony was produced using $3 \mathrm{~mL}$ of LB containing kanamycin $(20 \mathrm{mg} / \mathrm{mL})$ and was incubated for 16 hours at $37^{\circ} \mathrm{C}$, in a shaker.

\section{Induction of protein expression}

To induce expression of the GP60 protein, Luria Broth medium (LB) (Sigma-Aldrich) containing kanamycin $(20 \mathrm{mg} / \mathrm{mL})$ was added to reach a final volume of $30 \mathrm{~mL}$. The mix was incubated in a shaker for approximately 3 hours at $37^{\circ} \mathrm{C}$. At the ideal OD corresponding to $600 \mathrm{~nm}$ (a value between 0.6 and 0.8 ), an aliquot of $1 \mathrm{~mL}$ was sampled from each culture (of the non-induced sample) and the isopropyl $\beta$-D-thiogalactoside (IPTG) (Sigma-Aldrich) inducer was added and incubated under different conditions. 
Temperature $\left(25^{\circ} \mathrm{C}\right.$ and $\left.37^{\circ} \mathrm{C}\right)$, time (4, 8 and 16 hours) and IPTG inducer concentration $(0.1 \mathrm{mM}, 0.25 \mathrm{mM}, 0.5 \mathrm{mM}$ and $1.0 \mathrm{mM}$ ) were assayed in order to maximize the efficiency of protein expression.

The cultures (induced and non-induced) were analyzed on $12 \%$ sodium dodecyl sulphate-polyacrylamide gel electrophoresis (SDS-PAGE) and gels were stained with PageBlue ${ }^{\mathrm{TM}}$ protein staining solution (Thermo Fisher Scientific).

\section{Protein purification and refolding}

Bacterial lysis was performed by means of three rounds of sonication, each of 20 seconds, with 20 seconds of rest between rounds. The rGP60 was purified by means of affinity chromatography using the AKTA Pure chromatography system (GE Healthcare), Unicorn V5 software and Hi-Trap HP column (GE Healthcare).

The purified product was viewed using 12\% SDS-PAGE. The protein was dialyzed using the Amicon ${ }^{\circledR}$ Ultra-3K $0.5 \mathrm{~mL}$ column (Merck Millipore) and a dialysis buffer $\left(20 \mathrm{mM} \mathrm{NaH}_{2} \mathrm{PO}_{4}\right.$ and $500 \mathrm{mM} \mathrm{NaCl}$, at $\mathrm{pH}$ 7.4). A refolding buffer $(50 \mathrm{mM}$ Tris-base, $0.4 \mathrm{M}$ L-arginine, $1 \mathrm{mM}$ glutathione $(\mathrm{GSH})$ and $0.1 \mathrm{mM}$ glutathione disulfide (GSSG) at $\mathrm{pH} 8.0$ was used to store the protein (TSUMOTO et al., 2004). The protein concentration was measured using the spectrophotometer BioPhotometer Plus (Eppendorf).

\section{Production of anti-rGP60 $\operatorname{Ig} Y$}

In order to obtain polyclonal anti-rGP60 IgY, two hens were immunized as following: $0.5 \mathrm{mg}$ of rGP60 was mixed with complete Freund's adjuvant (Sigma-Aldrich) and was inoculated intramuscularly into different parts of the pectoral muscles with a total volume of $1 \mathrm{~mL}(500 \mu \mathrm{L}$ of antigen and $500 \mu \mathrm{L}$ of adjuvant). The inoculation was repeated with $0.25 \mathrm{mg}$ of antigen on the 10 th, $20^{\text {th }}$ and $30^{\text {th }}$ days using Freund's incomplete adjuvant (Sigma-Aldrich).

Serum samples were collected from the hens before the inoculation with rGP60 for use as negative controls. The indirect enzyme-linked immunosorbent assay (ELISA) was used to ascertain that inoculated hens were negative for anti-Cryptosporidium IgY. The antigen used in ELISA was produced from $23 \times 10^{6}$ C. parvum oocysts that were purified in cesium chloride gradient, diluted in PBS ( $\mathrm{pH} 7.4$ ) and sonicated in an ice bath for 10 cycles of ten seconds, with 20-second resting intervals between one cycle and the next. After protein assaying using the $\mathrm{BCA}^{\circledR}$ kit (Sigma-Aldrich), the antigen was used at a concentration of $10 \mu \mathrm{g} \cdot \mathrm{mL}^{-1}$. Serum samples were tested at a 1:1,000 dilution (serum $/ 5 \%$ skimmed milk). A conjugate composed of anti-chicken IgY (whole molecule)-peroxidase antibody produced in rabbit (Sigma-Aldrich) was used at a dilution of 1:5,000 (conjugate/5\% skimmed milk). After 20 minutes of addition of the substrate tetramethylbenzidine (Invitrogen), the enzymatic reaction was stopped with $1 \mathrm{~N} \mathrm{HCl}$. The reactions were read using a microplate reader (Labsystems Multiskan EX), with a $450 \mathrm{~nm}$ filter.

The IgY present in the egg yolks was purified using a delipidation-and-precipitation procedure that first separates the proteins from the lipid and then isolates the IgY fraction, in accordance with the manufacturer's instructions of the Pierce Chicken IgY purification kit (Thermo Fisher Scientific).

\section{Western blot}

The reactivity of anti-rGP60 IgY was verified using the Western blot technique. The rGP60 was separated by means of $12 \%$ SDS-PAGE and was transferred to a 0.45 -micron nitrocellulose membrane (Thermo Fisher Scientific). Lysozyme (14.3 kDa) and proteinase $\mathrm{K}(28.9 \mathrm{kDa})$ were also applied to the gel as negative controls.

The membrane was blocked for one hour with $2 \%$ bovine serum albumin (BSA) (Sigma-Aldrich) and incubated with anti-rGP60 IgY for 30 minutes. After three washing steps of 15 minutes each using $10 \mathrm{ml}$ of phosphate-buffered saline/Tween20 (PBS-T: $8 \mathrm{~g} \mathrm{NaCl}$, $0.2 \mathrm{~g} \mathrm{KCl}, 1.44 \mathrm{~g} \mathrm{Na}_{2} \mathrm{HPO}_{4}, 0.24 \mathrm{~g} \mathrm{KH}_{2} \mathrm{PO}_{4}, 0.5 \mathrm{ml}$ tween 20, q.s.p. $1 \mathrm{~L}$ distillated water, $\mathrm{pH} 7.4$ ), the membrane was incubated with anti-chicken IgY (whole molecule)-peroxidase antibody produced in rabbit (Sigma-Aldrich). It was then washed again three times with PBS-T, exposed to Enhanced Chemiluminescence (ECL) Western Blot Substrate (Thermo Fisher Scientific) and viewed using the ChemiDoc MP Imaging System (Bio-Rad).

\section{Indirect immunofluorescence}

The indirect immunofluorescence (IIF) test was performed to determine the reactivity of anti-gp60 polyclonal IgY towards C. parvum sporozoites.

C. parvum was used because of lack of availability of $C$. hominis sporozoites. Sporozoites of $C$. parvum were excysted from oocysts purified from the feces of naturally infected calves using water-ether sedimentation technique (MELONI \& THOMPSON, 1996) and cesium chloride gradients (ARROWOOD \& DONALDSON, 1996). To promote excystation, oocysts were incubated in acidified water ( $\mathrm{pH} 2.4$ ) for $20 \mathrm{~min}$ at $30^{\circ} \mathrm{C}$, centrifuged ( $10 \mathrm{~min}$ at $1800 \mathrm{~g}$ ) and resuspended in $1 \mathrm{ml}$ of HBSS ( $\mathrm{pH} 7.4$ ) which contained $0.02 \%$ sodium taurocholate (Sigma-Aldrich) for $1 \mathrm{~h}$ at $37^{\circ} \mathrm{C}$, centrifuged $(10 \mathrm{~min}$ at $1800 \mathrm{~g})$ and resuspended in $1 \mathrm{ml}$ of HBSS (pH 7.4) (KING et al., 2012).

The slides used for IIF were firstly treated with polylysine (Sigma-Aldrich) that had been diluted in the proportions of $1: 20$ in deionized water (ARROWOOD et al., 1991). To this, $25 \mu \mathrm{L}$ of $C$. parvum sporozoites (conserved in 3\% buffered formalin) were added. The sample drop was left to dry out completely at room temperature. Subsequently, $25 \mu \mathrm{L}$ of anti-GP60 polyclonal IgY was added at two dilutions (1:50 and 1:100) in 0.01 M PBS ( $\mathrm{pH} 7.2$ ), followed by incubation in a humid chamber at $37^{\circ} \mathrm{C}$, for 30 minutes. Following incubation, rabbit anti-chicken IgY-FITC IgG (Sigma-Aldrich) was added and the slide was incubated in a humid chamber at $37^{\circ} \mathrm{C}$, for 30 minutes. At the end of the incubation, the sample was washed using 0.01 M PBS ( $\mathrm{pH}$ 7.2). The slide mounting was completed using a cover slip over $25 \mu \mathrm{L}$ of mounting buffer (90\% glycerol in $0.01 \mathrm{M} \mathrm{PBS}$, at $\mathrm{pH} 7.2$; and $0.1 \mathrm{mg} / \mathrm{mL}$ of p-phenylenediamine) (PLATT \& MICHAEL, 1983). 
The reaction was read under an Olympus BX-50 microscope using a $100 \mathrm{~W}$ mercury light bulb with a U-MWU2 filter (DAPI) and a U-MWU2-B filter (fluorescein), at a magnification of $400 \times$.

\section{Results and Discussion}

The lack of GP60 protein expression using the BL21 CodonPlus and pRARE strains has motivated use of different strains of $E$. coli in attempting to solve this difficulty of expression, which is possibly related to protein insolubility or toxicity (SHAW \& MIROUX, 2003; BANDMANN \& NYGREN, 2007). Although many published papers have reported success regarding expression of heterologous proteins using $E$. coli, problems such as low levels or absence of protein expression, degradation and formation of inclusion bodies are common and hinder successful production of recombinant proteins (SORENSEN \& MORTENSEN, 2005). Alternatives such as varying the temperature or inducer concentration, and use of mutant strains of $E$. coli, modified through genetic engineering, may solve certain problems relating to protein expression (BANEYX \& MUJACIC, 2004).

Expression of GP60 protein was successfully achieved with the BL21 Xjb strain (Zymo Research) with a yield of $850 \mu \mathrm{g} / \mathrm{mL}$. The remaining strains (Rosetta, CodonPlus, pRARE, C41 and C43) did not form any colony on the culture plate or show any band corresponding to the induced protein. Two clones were used to standardize the processes of expression and protein purification. Several different assays were performed to maximize the efficiency of protein induction, i.e. incubation time: 4, 8 and 16 hours; inducer concentration: $0.1 \mathrm{mM}, 0.25 \mathrm{mM}, 0.5 \mathrm{mM}$ and $1.0 \mathrm{mM}$; and incubation temperature: $25^{\circ} \mathrm{C}$ and $37^{\circ} \mathrm{C}$. These showed that the optimum conditions for expression of the glycoprotein GP60 consisted of using $1 \mathrm{mM}$ of IPTG inducer, at $37^{\circ} \mathrm{C}$ with 16 hours of incubation (Figure 1).

The anti-rGP60 IgY used for Western blot was successfully extracted and purified to a final concentration of $22 \mathrm{mg} / \mathrm{mL}$. In Figure 2, a $60 \mathrm{kDa}$ band can be seen, and this confirms that binding of anti-rGP60 IgY to the rGP60. We also observed the presence of a clear trail below the band of interest, which was probably due to protein degradation, thus resulting in antigens of lower molecular weight that were recognized by the polyclonal IgY (ZHANG, 2003).

Indirect immunofluorescence using polyclonal anti-C. hominis GP60 IgY made it possible to view C. parvum sporozoites (Figure 3). The positive results from the IIF test showed that the anti-C. hominis GP60 IgY recognized antigens that were present in $C$. parvum sporozoites. This result was expected since these two Cryptosporidium species, as well as other genetically similar intestinal Cryptosporidium species present cross-reactivity in various diagnostic techniques (JEX et al., 2008).

In the present study, the gp60 gene of $C$. hominis was successfully expressed in the expression system of the $E$. coli BL21 Xjb strain. Anti-rGP60 IgY was produced and purified successfully, and its binding to $\mathrm{rGP} 60$ and $C$. parvum sporozoites was confirmed. The rGP60 and anti-rGP60 IgY thus generated may be used for research and for the development of diagnostic methods for cryptosporidiosis such as antigen capture ELISA for the detection of Cryptosporidium antigens in fecal samples and the indirect ELISA aiming seroepidemiology studies in animals and humans.

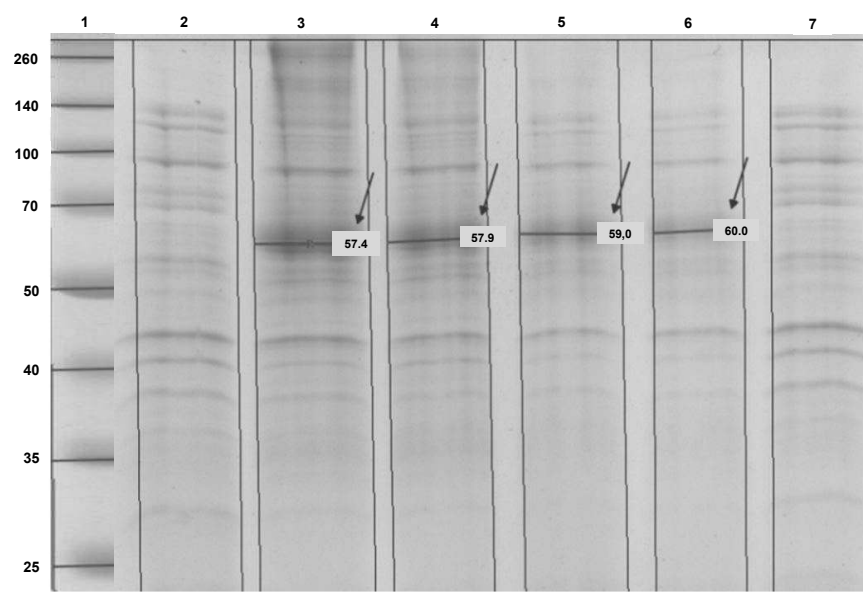

Figure 1. SDS-PAGE (12\%) of the inducer concentration test. 1:Protein Ladder (kDa); 2 and 7: non-induced; 3: 1 mM IPTG; 4 0.5 mM IPTG; 5: 0.25 mM IPTG, and 6: $0.1 \mathrm{mM} \mathrm{IPTG.} \mathrm{The} \mathrm{arrows}$ indicate the bands corresponding to $\mathrm{rGP} 60$. The gel was stained with PageBlue $^{\mathrm{TM}}$ protein staining solution (Thermo Scientific).

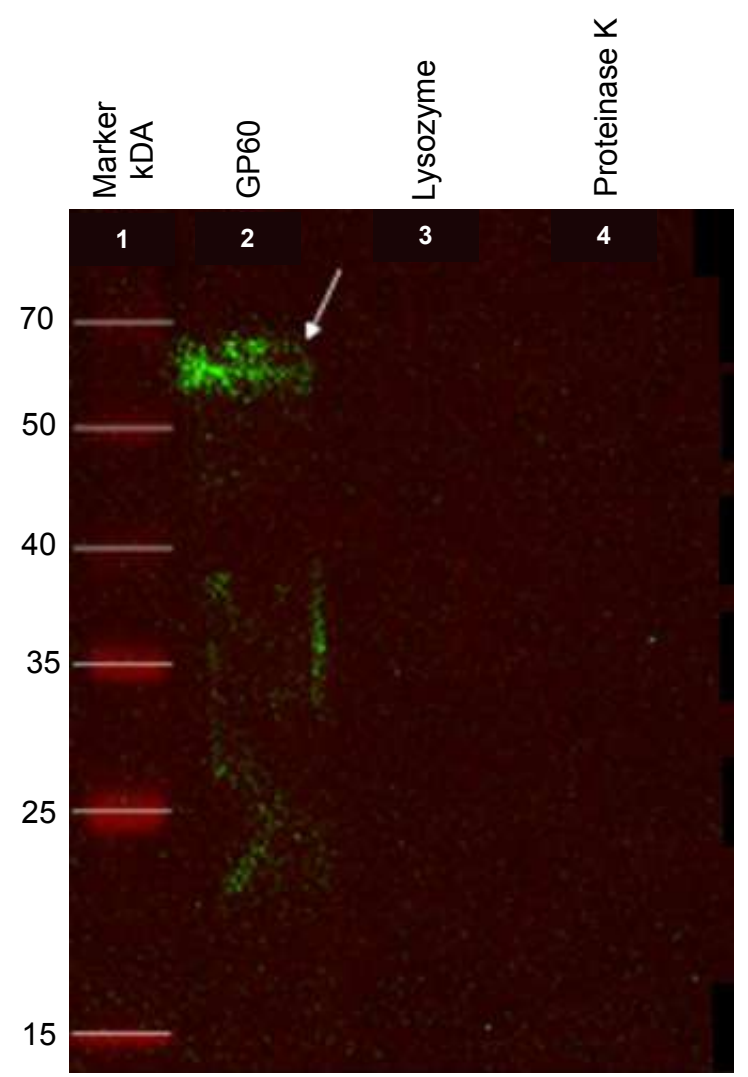

Figure 2. Western blot analysis of purified rGP60. Chemiluminescence. Arrow: purified protein. Negative controls: lysozyme and proteinase K. 


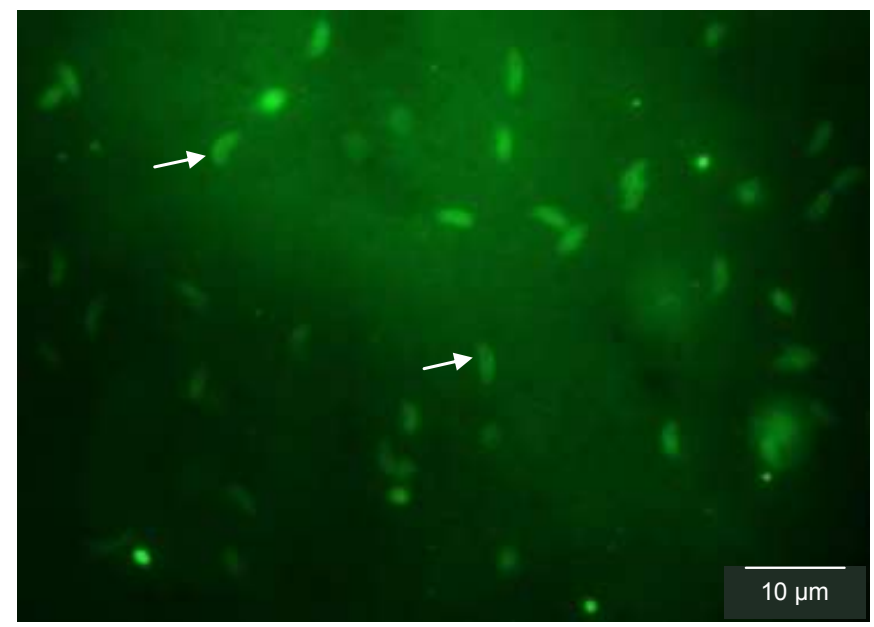

Figure 3. Sporozoites of Cryptosporidium parvum. Indirect immunofluorescence using anti-Cryptosporidium hominis rGP60 glycoprotein policlonal IgY.

\section{Acknowledgements}

We would like to thank the São Paulo Research Foundation (Fundação de Amparo à Pesquisa do Estado de São Paulo - FAPESP) for financial support (2013/06622-3).

\section{References}

Arrowood MJ, Donaldson K. Improved purification methods for calfderived Cryptosporidium parvum oocysts using discontinuous sucrose and cesium chloride gradients. J Eukaryot Microbiol 1996; 43(5): 89S. PMid:8822880. http://dx.doi.org/10.1111/j.1550-7408.1996.tb05015.x.

Arrowood MJ, Sterling CR, Healey MC. Immunofluorescent microscopical visualization of trails left by gliding Cryptosporidium parvum sporozoites. J Parasitol 1991; 77(2): 315-317. PMid:2010865. http://dx.doi. org/10.2307/3283104.

Bandmann N, Nygren PA. Combinatorial expression vector engineering for tuning of recombinant protein production in Escherichia coli. Nucleic Acids Res 2007; 35(5): e32. http://dx.doi.org/10.1093/nar/gkl1171.

Baneyx F, Mujacic M. Recombinant protein folding and misfolding in Escherichia coli. Nat Biotechnol 2004; 22(11): 1399-1408. PMid:15529165. http://dx.doi.org/10.1038/nbt1029.

Cacciò SM, Pozio E. Advances in the epidemiology, diagnosis and treatment of cryptosporidiosis. Expert Rev Anti Infect Ther 2006; 4(3): 429-443. PMid:16771620. http://dx.doi.org/10.1586/14787210.4.3.429.

Cevallos AM, Bhat N, Verdon R, Hamer DH, Stein B, Tzipori S, et al. Mediation of Cryptosporidium parvum infection in vitro by mucin-like glycoproteins defined by a neutralizing monoclonal antibody. Infect Immun 2000; 68(9): 5167-5175. PMid:10948140. http://dx.doi.org/10.1128/ IAI.68.9.5167-5175.2000.

Fayer R, Morgan UM, Upton SJ. Epidemiology of Cryptosporidium: transmission, detection and identification. Int J Parasitol 2000; 30(1213): 1305-1322. PMid:11113257. http://dx.doi.org/10.1016/S00207519(00)00135-1.
Fournet N, Deege MP, Urbanus AT, Nichols G, Rosner BM, Chalmers RM, et al. Simultaneous increase of Cryptosporidium infections in the Netherlands, the United Kingdom and Germany in late summer season, 2012. Euro Surveill 2013; 18(2): 1-5. PMid:23324424.

Jex A, Gasser RB. Genetic richness and diversity in Cryptosporidium hominis and C. parvum reveals major knowledge gaps and a need for the application of "next generation" technologies: research review. Biotechnol Adv 2010; 28(1): 17-26. PMid:19699288. http://dx.doi.org/10.1016/j. biotechadv.2009.08.003.

Jex AR, Smith HV, Monis PT, Campbell BE, Gasser RB. Cryptosporidium: biotechnological advances in the detection, diagnosis and analysis of genetic variation. Biotechnol Adv 2008; 26(4): 304-317. PMid:18430539. http://dx.doi.org/10.1016/j.biotechadv.2008.02.003.

Karanis P, Kourenti C, Smith HV. Waterborne transmission of protozoan parasites: a worldwide review of outbreaks and lessons learnt. J Water Health 2007; 5(1): 1-38. PMid:17402277. http://dx.doi.org/10.2166/ wh.2006.002.

King BJ, Keegan AR, Phillips R, Fanok S, Monis PT. Dissection of the hierarchy and synergism of the bile derived signal on Cryptosporidium parvum excystation and infectivity. Parasitology 2012; 139(12): 15331546. PMid:22894830. http://dx.doi.org/10.1017/S0031182012000984.

Leitch GJ, He Q. Cryptosporidiosis: an overview. J Biomed Res 2012; 25(1): 1-16. PMid:22685452. http://dx.doi.org/10.1016/S16748301(11)60001-8.

Meloni BP, Thompson RCA. Simplified methods for obtaining purified oocysts from mice and for growing Cryptosporidium parvum in vitro. J Parasitol 1996; 82(5): 757-762. PMid:8885885. http://dx.doi. org/10.2307/3283888

O'Connor RM, Wanyiri JW, Cevallos AM, Priest JW, Ward HD. Cryptosporidium parvum glycoprotein gp 40 localizes to the sporozoite surface by association with gp15. Mol Biochem Parasitol 2007; 156(1): 80-83. PMid:17719100. http://dx.doi.org/10.1016/j.molbiopara.2007.07.010.

Pauly D, Dorner M, Zhang X, Hlinak A, Dorner B, Schade R. Monitoring of laying capacity, immunoglobulin $Y$ concentration, and antibody titer development in chickens immunized with ricin and botulinum toxins over a two-year period. Poult Sci 2009; 88(2): 281-290. PMid:19151341. http://dx.doi.org/10.3382/ps.2008-00323.

Platt JL, Michael AF. Retardation of fading and enhancement of intensity of immunofluorescence by p-phenylenediamine. J Histochem Cytochem 1983; 31(6): 840-842. PMid:6341464. http://dx.doi.org/10.1177/31.6.6341464.

Preidis GA, Wang HC, Lewis DE, Castellanos-Gonzalez A, Rogers KA, Graviss EA, et al. Seropositive human subjects produce interferon gamma after stimulation with recombinant Cryptosporidium hominis gp15. Am J Trop Med Hyg 2007; 77(3): 583-585. PMid:17827383.

Puigbo P, Guzmen E, Romeu A, Garcia-Vallve S. OPTIMIZER: a web server for optimizing the codon usage of DNA sequences. Nucleic Acids Res 2007; 35: W126-W131. PMCid: PMC1933141. http://dx.doi. org/10.1093/nar/gkm219.

Schade R, Calzado EG, Sarmiento R, Chacana PA, Porankiewicz-Asplund J, Terzolo HR. Chicken egg yolk antibodies (IgY-technology): a review of progress in production and use in research and human and veterinary medicine. Altern Lab Anim 2005; 33(2): 129-154. PMid:16180988.

Shaw AZ, Miroux B. A general approach for heterologous membrane protein expression in Escherichia coli. In: Selinsky BS. Membrane protein 
protocols: expression, purification, and characterization (Methods in Molecular Biology). Totowa: Humana Press; 2003. p. 23-35.

Sorensen HP, Mortensen KK. Soluble expression of recombinant proteins in the cytoplasm of Escherichia coli. Microb Cell Fact 2005; 4(1): 1. PMid:15629064. http://dx.doi.org/10.1186/1475-2859-4-1.

Strong WB, Gut J, Nelson RG. Cloning and sequence analysis of a highly polymorphic Cryptosporidium parvum gene encoding a 60-kilodalton glycoprotein and characterization of its 15- and 45-kilodalton zoite surface antigen products. Infect Immun 2000; 68(7): 4117-4134. PMid:10858229. http://dx.doi.org/10.1128/IAI.68.7.4117-4134.2000.
Tsumoto K, Umetsu M, Kumagai I, Ejima D, Philo JS, Arakawa T. Role of arginine in protein refolding, solubilization, and purification. Biotechnol Prog 2004; 20(5): 1301-1308. PMid:15458311. http://dx.doi. org/10.1021/bp0498793.

Xiao L, Ryan UM. Cryptosporidiosis: an update in molecular epidemiology. Curr Opin Infect Dis 2004; 17(5): 483-490. PMid:15353969. http:// dx.doi.org/10.1097/00001432-200410000-00014.

Zhang WW. The use of gene-specific IgY antibodies for drug target discovery. Drug Discov Today 2003; 8(8): 364-371. PMid:12681940. http://dx.doi.org/10.1016/S1359-6446(03)02655-2. 